\title{
Ac Recombination Velocity in a Lamella Silicon Solar Cell
}

\section{Matar Gueye', Hawa Ly Diallo1, Attoumane Kosso Mamadou Moustapha², Youssou Traore1, Ibrahima Diatta ${ }^{1}$, Gregoire Sissoko ${ }^{1}$}

${ }^{1}$ Laboratory of Semiconductors and Solar Energy, Physics Department, Faculty of Science and Technology, University Cheikh Anta Diop, Dakar, Senegal

${ }^{2}$ School of Mines and Geology, Niamey, Niger

Email: gsissoko@yahoo.com

How to cite this paper: Gueye, M., Diallo, H.L., Moustapha, A.K.M., Traore, Y., Diatta, I. and Sissoko, G. (2018) Ac Recombination Velocity in a Lamella Silicon Solar Cell. World Journal of Condensed Matter Physics, 8, 185-196.

https://doi.org/10.4236/wjcmp.2018.84013

Received: October 18, 2018

Accepted: November 9, 2018

Published: November 12, 2018

Copyright $\odot 2018$ by authors and Scientific Research Publishing Inc. This work is licensed under the Creative Commons Attribution International License (CC BY 4.0).

http://creativecommons.org/licenses/by/4.0/

\begin{abstract}
The silicon solar cell with series-connected vertical junction is studied with different lamella widths-the expression of the ac recombination velocity of the excess minority carrier at the back surface is established. Spectroscopy technique reveals dominated impact of the lamella widths of the base.
\end{abstract}

\section{Keywords}

Silicon Solar Cell-Vertical Junction Series, Ac Recombination Velocity, Lamella Width

\section{Introduction}

The techniques of characterization of solar cell for quality control [1] [2] [3] improve the fabrication processes, go through experimental [4] and theoretical [5] studies in static [6] or dynamic transient [7] [8] [9] and frequency [10] [11] [12].

The phenomenological parameters [13], which allow this quality control, are the carrier recombination velocity:

1 ) in the bulk [14], defined by the diffusion length $(L)$ and coefficient $(D)$, lifetime $(\tau)$ of excess minority carrier.

2) on the surfaces [15] [16], i.e., recombination velocity $(S f)$ at the junction $(\mathrm{n}-\mathrm{p})$ [17] [18], $(S b)$ at the junction $\left(\mathrm{p}-\mathrm{p}^{+}\right)$[19] [20], and $(S g)$ at the grain boundaries in the 3-dimensional [21] [22] model.

The solar cell is placed under different operating modes [23] and for different illuminations: monochromatic [24], polychromatic [25], constant multspectral 
[26].

The solar cell can be maintained under different experimental conditions while varying: temperature [27] [28], electric field [29] [30], magnetic field [31] [32], or irradiation energy of particles [33] [34] [35].

To achieve low cost solar concentrator cell, vertical multi-junction (VMJ) cells have been manufactured [36]. There are two types of VMJ [28] [37] [38], according to the connection between cell units, in view to improve, either charge carrier current collection or tension. Thus, series-connected VMJ [39] and parallel-connected VMJ [40] have been process, allowing poor minority carrier diffusion length to be collected, by use of silicon material regardless of crystal orientation (multi-crystalline or ribbon).

In our study, the structure of the series-connected vertical junction solar cell [39] with different lamella widths $(H)$, is investigated in order to determine the recombination velocity of the excess minority carrier at the back surface. This new expression of the ac recombination velocity is analyzed through Bode and Nyquist diagrams, and is shown to depend strongly upon the lamella widths of the base $(H)$.

\section{Theory}

Figure 1 shows series-connected vertical multi-junction solar cells where each base (lamella) is framed by two emitters. Between emitter $\left(\mathrm{n}^{+}\right)$and base (p) we have the space charge region (SCR), called the junction. And at the back side of each base region, there is a high doping layer $\left(\mathrm{p}^{+}\right)$giving rise to a back surface field (BSF), which induced the back surface recombination velocity $(S b)$ (Figure 2).

In this series-connected architecture, each solar cell unitis separated on both sides by metal contacts [36] [37] [39].

The continuity equation at which the density of minority charge carriers in excess obeyed $\delta(x, t)$ at the position $x$ in the base, in an instant $t$, is given by [41] [42]:

$$
D(\omega) \cdot \frac{\partial^{2} \delta(x, t)}{\partial x^{2}}-\frac{\delta(x, t)}{\tau}=-G(z, t)+\frac{\partial \delta(x, t)}{\partial t}
$$

The ac component of the excess minority density is in the following form:

$$
\delta(x, t)=\delta(x) \cdot \mathrm{e}^{j \omega t}
$$

$j$ is the complex notation.

With $\delta(x)$ is the steady state minority carrier density position dependent.

The expression of the ac generation rate $G(z, t)$ of the minority carrier at depth $z$, is given by [43]:

$$
G(z, t)=g(\omega, \alpha, z) \cdot \mathrm{e}^{J \omega \cdot t}
$$

with:

$$
g(\omega, \alpha, z)=K(\omega, \alpha) \cdot \exp (-\alpha \cdot z)
$$




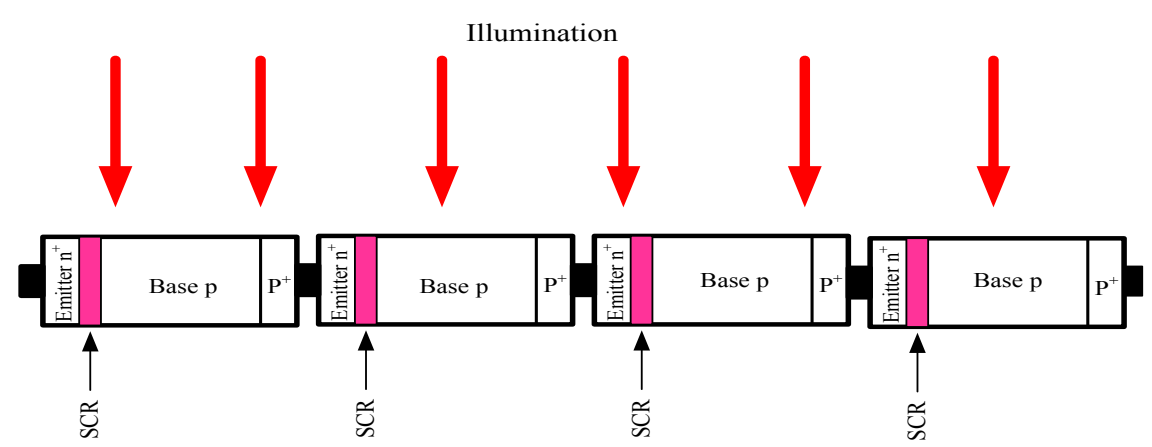

Figure 1. Schematic of a series-connected vertical multi-junction solar cell.

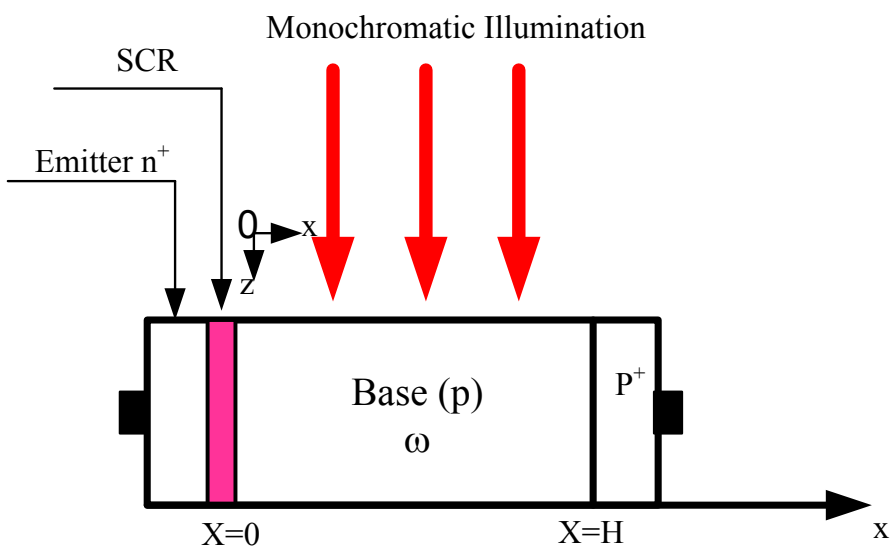

Figure 2. Across section of the vertical junction.

and

$$
K(\omega, \alpha)=-\left[\frac{\alpha \cdot I(\lambda) \cdot(1-R(\lambda))}{D(\omega) \cdot\left[\alpha^{2}-\frac{1}{L(\omega)^{2}}\right]}\right]
$$

$I(\lambda)$ is the intensity of the monochromatic illumination of wavelength $\lambda . \alpha$ is the absorption coefficient of the monochromatic light incident on the cell and $R$ $(\lambda)$ its reflectance coefficient.

$D(\omega)$ and $L(\omega)$ are respectively, the excess ac minority carrier diffusion coefficient and diffusion length in the base subjected to illumination in frequency modulation $(\omega)$.

$L(\omega)$ and $D(\omega)$ ac expressions are giving by [12] [44]:

$$
\begin{aligned}
& D(\omega)=D \cdot\left[\frac{1}{1+(\omega \cdot \tau)^{2}}-\frac{j \cdot \omega \cdot \tau}{1+(\omega \cdot \tau)^{2}}\right] \\
& L(\omega)=\sqrt{D \cdot\left[\frac{\tau}{1+(\omega \cdot \tau)^{2}}-\frac{j \cdot \omega \cdot \tau^{2}}{1+(\omega \cdot \tau)^{2}}\right]}
\end{aligned}
$$

where $D$ denotes the diffusion constant and $\tau$ the bulk lifetime in steady state. 
By substituting Equation (1) together with Equation (2) and Equation (3), leads to:

$$
\frac{\partial^{2} \delta(x, \omega)}{\partial x^{2}}-\frac{\delta(x, \omega)}{L(\omega)^{2}}+\frac{g(\omega, \alpha, z)}{D(\omega)}=0
$$

Thus the resolution of Equation (6) gives the excess minority carrier density in the base through the following expression:

$$
\delta(x, \omega, \alpha, z)=A \cosh \left(\frac{x}{L(\omega)}\right)+B \sinh \left(\frac{x}{L(\omega)}\right)+K(\omega, \alpha) \cdot \exp (-\alpha \cdot z)
$$

with coefficients $A$ et $B$ are deduced from the boundary conditions:

1) At the junction $(x=0)$, the expression of the photocurrent $\operatorname{Jph}(0, \omega, \alpha, z)$ [20] [45] [46] is given by:

$$
\left.q \cdot D(\omega) \frac{\partial \delta(x, \omega, \alpha, z)}{\partial x}\right|_{x=0}=q \cdot S f \cdot \delta(0, \omega, \alpha, z)=\operatorname{Jph}(0, \omega, \alpha, z)
$$

2) On the back side in the base at $x=H$.

$$
\left.\frac{\partial \delta(x, \omega, \alpha, z)}{\partial x}\right|_{x=H}=-\frac{S b}{D(\omega)} \delta(H, \omega, \alpha, z)
$$

$S f$ and $S b$ are respectively the recombination velocities of the excess minority carrier at the junction and at the back surface. The recombination velocity $S f$ reflects the charge carrier velocity of passage at the junction, in order to participate in the photocurrent. It is then imposed, by the external load which fixes the solar cell operating point [12] [45] [46]. It has an intrinsic component, which represents the carrier losses associated with the shunt resistor in the solar cell electrical equivalent model [47] [48] [49]. The excess minority carrier recombination velocity $\mathrm{Sb}$ on the back surface is associated with the presence of the $\mathrm{p}^{+}$layer, which generates an electric field for throwing back the charge carrier toward the junction [50].

After calculation, the following expression of the ac excess minority carrier density is obtained by:

$$
\begin{aligned}
\delta(x, \omega, \alpha, z)= & A(H, \omega, \alpha, z, S f, S b) \cosh \left(\frac{x}{L(\omega)}\right) \\
& +B(H, \omega, \alpha, z, S f, S b) \sinh \left(\frac{x}{L(\omega)}\right) \\
& +K(\omega, \alpha) \cdot \exp (-\alpha \cdot z)
\end{aligned}
$$

\section{Results and Discussions}

The excess minority carrier recombination velocity at the back surface is deduced from the resolution of the following equation [45] [46]:

$$
\frac{\partial J_{p h}(H, \omega, \alpha, z, S f, S b)}{\partial S f}=0
$$


Solving Equation (13) leads to two solutions [45] [46] [47] [49]. The intrinsic solution, i.e., that which is not a function of the absorption coefficient, is retained and its expression is given by:

$$
S b(\omega, H)=-\frac{D(\omega)}{L(\omega)} \cdot \tanh \left(\frac{H}{L(\omega)}\right)
$$

$S b$ in complex form (real and imaginary components) is presented by analogy of the effect of Maxwell-Wagner-Sillars (MWS) model [50] [51] [52] and can be written as:

$$
S b(\omega, H)=S b^{\prime}(\omega, H)+J \cdot S b^{\prime \prime}(\omega, H)
$$

We define the ac phase as following equation:

$$
\tan (\phi(\omega, H))=\frac{S b^{\prime \prime}(\omega, H)}{S b^{\prime}(\omega, H)}
$$

$S b_{\text {ampl }}(\omega, H)$ and $\phi(\omega, H)$ correspond to the amplitude and phase component of $S b$.

We represent in Figure 3 the spectra of the excess minority carrier recombination velocity at the back surface for different lamella $H$ thickness values.

Figure 3 shows a decrease in the amplitude of the excess minority carrier recombination at the back surface when $(H)$ the thickness of the lamella increases.

The large $(H)$ thicknesses give weak oscillation periods. Thus whatever the lamella width, the oscillation is around a fixed $(S b 0)$ value of the excess minority carrier recombination velocity.

Figure 4 gives the profile of $S b$ the amplitude of the recombination velocity as a function of $H$ the base thickness, for given values of the modulation frequency of the illumination.

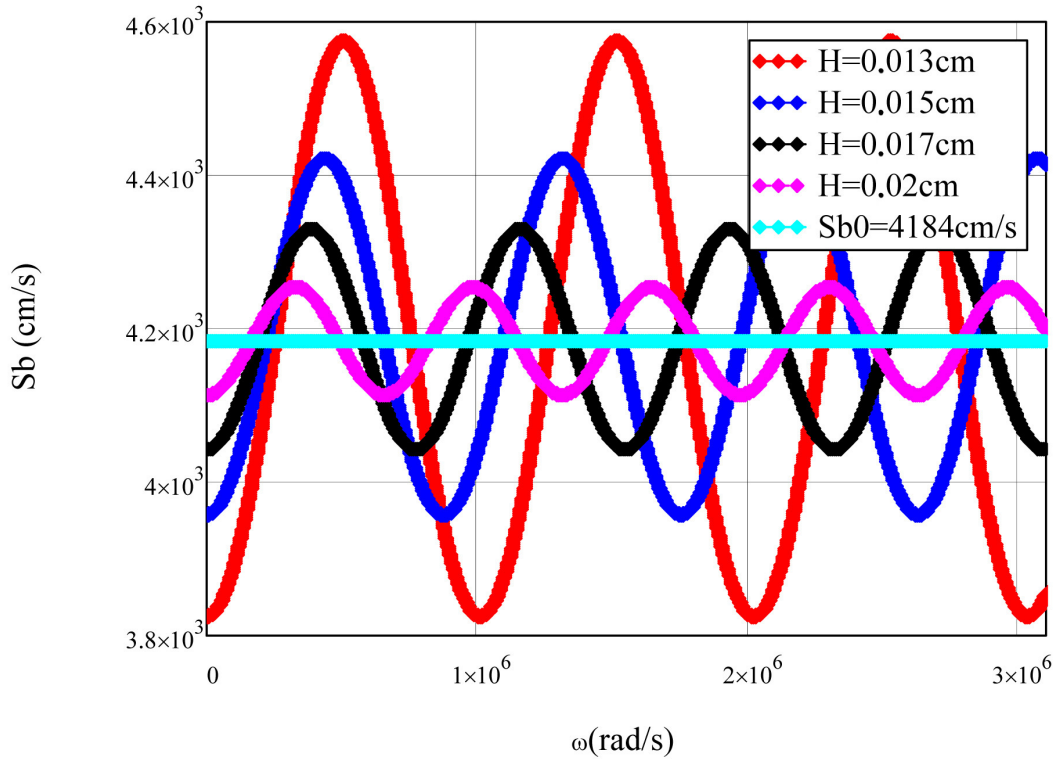

Figure 3. Recombination velocity of the minority charge carriers at the back surface $S b$ versus frequency for different lamella width values. 


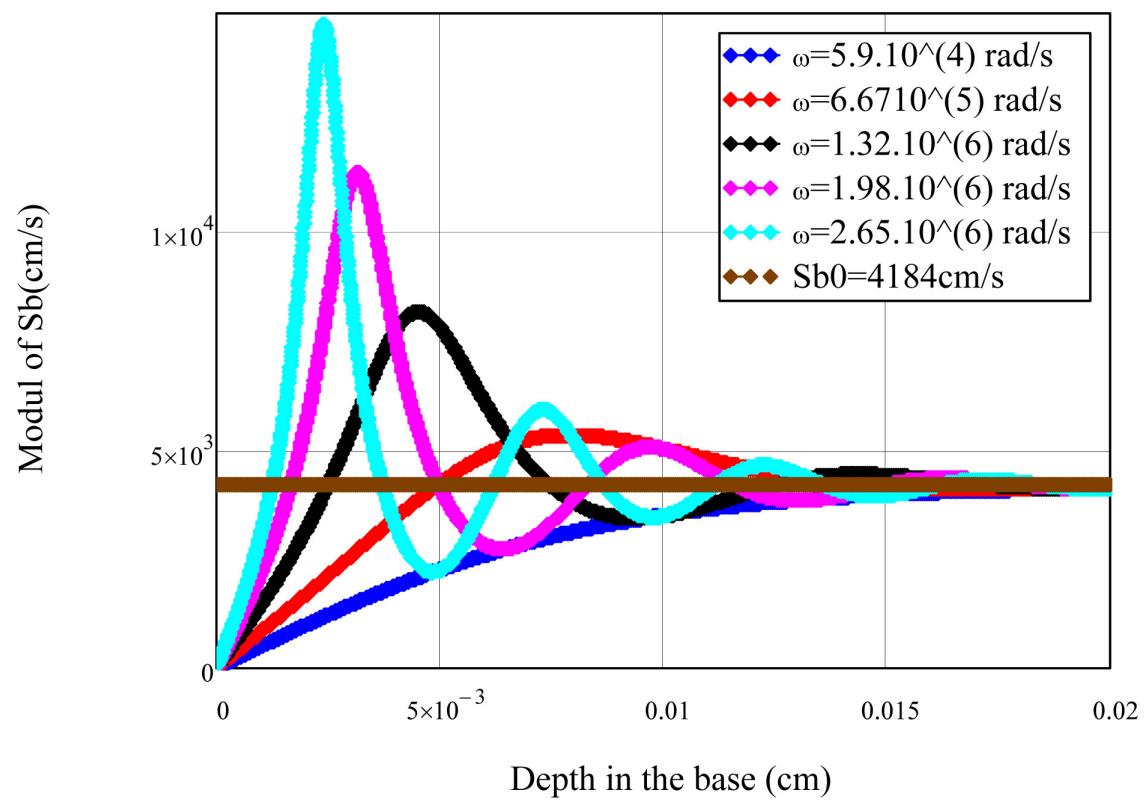

Figure 4. Back surface Recombination velocity as function of lamella width for different frequencies. $D=35 \mathrm{~cm}^{2} / \mathrm{s} ; \tau=2 \times 10^{-6} \mathrm{~s}$.

For high range frequencyvalues $(\omega \tau>1)$ we observe a damped sinusoid (aperiodic response), to then give the appearance of an exponential growth. For large lamella width, these curves tend towards an asymptote $(S b 0=4184 \mathrm{~cm} / \mathrm{s})$, whatever the frequency.

The amplitude and the phase spectra of the recombination velocity $(S b)$ are given respectively in Figure 5(a) and Figure 5(b) with different thicknesses (Bode diagrams).

On the frequency axis, the region corresponding to the frequencies below $10^{4}$ $\mathrm{rd} / \mathrm{s}($ i.e. $\omega \tau \ll 1)$, constitutes the steady state.

In this zone the amplitude of $S b_{A m p l}$ believes with the thickness $H$. The phase remains constant and obviously equal to zero.

In high frequency region $10^{4} \mathrm{rd} / \mathrm{s}<\omega$, tarts the dynamic regime i.e. $\omega \tau \gg 1$ ), showing a sinusoid of amplitude $\left(S b_{A m p}\right)$, oscillating around $S b 0$, the asymptotical recombination velocity, with periods $T_{S b}$ decreasing with $H$ (see Table 1 ).

The phase spectrum shows regular sinusoids with constant amplitudes $\phi_{\text {amp }}$ for each given $H$ lamella widths, but decreases with $H$. The period $T \phi_{\text {ampl }}$ of these oscillations decreases with the lamella thickness $H$ (see Table 2).

Figure 6 produces the representation of the imaginary part as a function of the real part of the recombination velocity $S b$.

The circles obtained have for their center $S b 0$, on the axis of the reals. The radius of the circles increases when the lamella thickness $H$ decreases. According to the spectroscopy techniques [51] [52], the intersections of the circles with the real axis, at high frequency range, indicate the presence of a series resistance which decreases with $H$ the lamella thickness. The negative part of circles indicates a capacitive phenomenon $(C)$, while the positive part, an inductive 


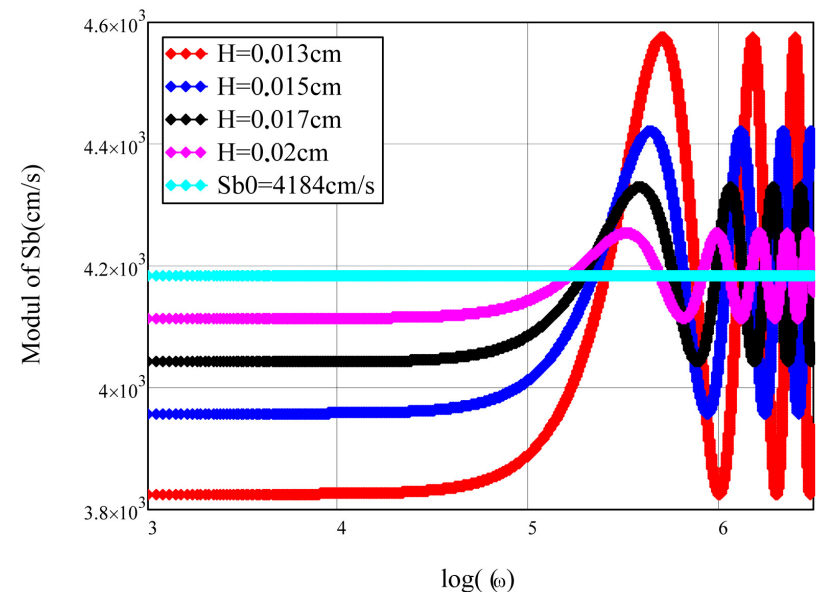

(a)

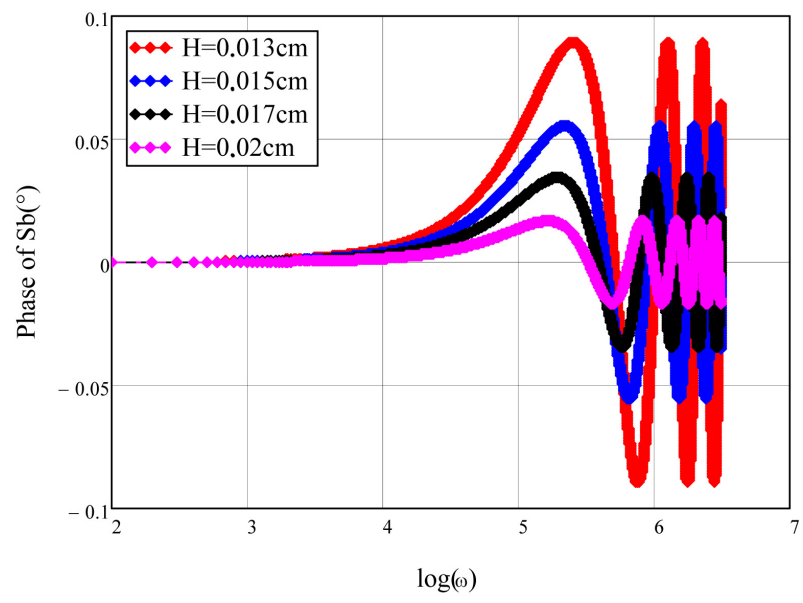

(b)

Figure 5. Bode diagram of $S b$ (a) and its phase (b) for different lamella widths.

Table 1. Sb periods for different lamella widths.

\begin{tabular}{ccccc}
\hline$H(\mathrm{~cm})$ & 0.013 & 0.015 & 0.017 & 0.02 \\
\hline$(S b A m p I)\left(10^{5} \mathrm{rad} / \mathrm{s}\right)$ & 10.070 & 8.776 & 7.700 & 6.472 \\
$T(S b A m p I)\left(10^{-6} \mathrm{~s}\right)$ & 6.240 & 7.160 & 8.160 & 9.700 \\
$S b(A m p I)(\mathrm{cm} / \mathrm{s})$ & 4573 & 4422 & 4329 & 4254 \\
\hline
\end{tabular}

Table 2. Phase period for different lamella widths.

\begin{tabular}{ccccc}
\hline$H(\mathrm{~cm})$ & 0.013 & 0.015 & 0.017 & 0.02 \\
\hline$\phi(A m p I)$ & 0.089 & 0.055 & 0.034 & 0.017 \\
$\omega_{\phi}(A m p I)\left(10^{5} \mathrm{rad} / \mathrm{s}\right)$ & 10.120 & 8.584 & 7.952 & 6.604 \\
$T_{\phi}\left(10^{-6} \mathrm{~s}\right)$ & 6.200 & 7.320 & 7.902 & 9.515 \\
\hline
\end{tabular}

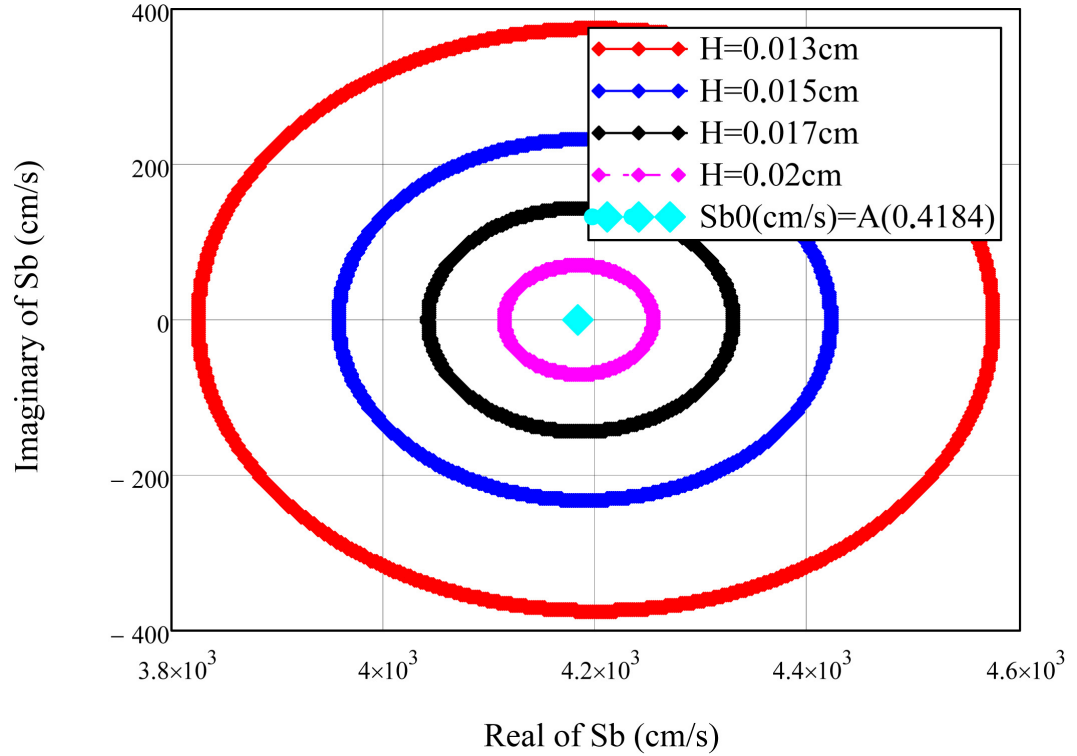

Figure 6. Imaginary component versus real component of $S b$ for different $H$ lamella widths. 
phenomenon $(L h)$, both decrease with the lamella thickness $H$. The ac equivalent circuit of $S b$, suggests that, the capacitor and the inductor are associated in parallel and connected in series with a resistance (obtained for large frequency) [53] [54] [55].

\section{Conclusion}

The series-connected vertical multi-junction silicon solar cell was studied under frequency modulated illumination and yielded the determination of the ac back surface recombination velocity of the excess minority carrier. It is expressed as dependent of both lamella thickness and illumination frequency. The excess minority carrier recombination is investigated through the Bode diagrams of its amplitude and phase. The study also showed through the Nyquist diagram, the capacitive, inductive and resistive responses of the ac recombination velocity $\mathrm{Sb}$, as well as the effect of the thickness of the lamella based solar cell.

\section{Conflicts of Interest}

The authors declare no conflicts of interest regarding the publication of this paper.

\section{References}

[1] (1995) Silicon Solar Cells, Advanced Principles and Practice. Centre for Photovoltaic Devices and Systems, 258-265.

[2] Liou, J.J. and Wong, W.W. (1992) Comparison and Optimization of the Performance of Si and GaAs Solar Cells. Solar Energy Materials and Solar Cells, 28, 9-28. https://doi.org/10.1016/0927-0248(92)90104-W

[3] Shockley, W. (1950) Electrons and Holes in Semiconductors. Van Nostrand, New York, 558 .

[4] Jung, T.-W., Lindholm, F.A. and Neugroschel, A. (1984) Unifying View of Transient Responses for Determining Lifetime and Surface Recombination Velocity in Silicon Diodes and Back-Surface-Field Solar Cells, with Application to Experimental Short-Circuit-Current Decay. IEEE Transactions on Electron Devices, 31, 588-595. https://doi.org/10.1109/T-ED.1984.21573

[5] Jain, S.C. (1983) The Effective Lifetime in Semicrystalline Silicon. Solar Cells, 9, 345-352. https://doi.org/10.1016/0379-6787(83)90028-5

[6] Sissoko, G., Nanéma, E., Corréa, A., Biteye, P.M., Adj, M. and Ndiaye, A.L. (1998) Silicon Solar Cell Recombination Parameters Determination Using the Illuminated I-V Characteristic. Renewable Energy, 3, 1848-1851.

[7] Zondervan, A., Verhoef, L.A. and Lindholm, F.A. (1988) Measurement Circuits for Silicon-Diode and Solar Cells Lifetime and Surface Recombination Velocity by Electrical Short-Circuit Current Delay. IEEE Transactions on Electron Devices, 35, 85-88. https://doi.org/10.1109/16.2419

[8] Von Roos, O. (1981) Analysis of the Photo Voltage Decay (PVD) Method for Measuring Minority Carrier Lifetimes in P-N Junction Solar Cells. Journal of Applied Physics, 52, 5833-5837. https://doi.org/10.1063/1.329478

[9] Lindholm, F.A., Liou, J.J., Neugroschel, A. and Jung, T.W. (1987) Determination of 
Lifetime and Surface Recombination Velocity of p-n Junction Solar Cells and Diodes by Observing Transients. IEEE Transactions on Electron Devices, 34, 277-283.

[10] Kumar, S., Singh, P.K. and Chilana, G.S. (2009) Study of Silicon Solar Cell at Different Intensities of Illumination and Wavelengths Using Impedance Spectroscopy. Solar Energy Materials and Solar Cells, 93, 1881-1884. https://doi.org/10.1016/j.solmat.2009.07.002

[11] Kumar, S., Singh, P.K. and Dhariwal, S.R. (2010) Effect of Surface Passivation on Generation and Recombination Lifetimes in Silicon Wafer Studied by Impedance Spectroscopy. Applied Physics Letters, 3, 162109.

[12] Mandelis, A. (1989) Coupled ac Photocurrent and Photothermal Reflectance Response Theory of Semiconducting p-n Junctions. I. Journal of Applied Physics, 66, 5572-5583. https://doi.org/10.1063/1.343662

[13] Dhariwal, S.R. and Vasu, N.K. (1981) A Generalized Approach to Lifetime Measurement in p-n Junction Solar Cells. Solid-State Electronics, 24, 915-927. https://doi.org/10.1016/0038-1101(81)90112-X

[14] De, S.S., Ghosh, A.K., Bera, M., Hajra, A. and Haldar, J.C. (1996) Influence of Built-In Potential on the Effective Surface Recombination Velocity for a Heavily Doped High-Low Junction. Physica B, 228, 363-368. https://doi.org/10.1016/S0921-4526(96)00474-7

[15] Arora, J.D, Singh, S.N. and Mathur, P.C. (1981) Surface Recombination Effects on the Performance of n+-p Step and Diffused Junction Silicon Solar Cells. Solid State Electronics, 24, 739-747. https://doi.org/10.1016/0038-1101(81)90055-1

[16] Xing, Y., Han, P., Wang, S., Liang P., Lou, S., Zhang, Y., Hu, S., Zhu, H., Mi, Y. and Zhao, C. (2013) Analysis of Effects of Front and Back Surface of One Vertical Silicon Dopants Multi-Junction Solar Cell by 2D Numerical Simulation. Science China Technological Sciences, 56, 2798-2807.

[17] Diao, A., Wade, M., Thiame, M. and Sissoko, G. (2017) Bifacial Silicon Solar Cell Steady Photoconductivity under Constant Magnetic Field and Junction Recombination Velocity Effects. Journal of Modern Physics, 8, 2200-2208. https://doi.org/10.4236/jmp.2017.814135

[18] Barro, F.I., Nanéma, E., Werème, A., Zougmoré, F. and Sissoko, G. (2001) Bulk and Surface Recombination Measurement in Silicon Double Sided Surface Field Solar Cell under Constant White Bias Illumination. Proceedings of the 17 th European Photovoltaic Solar Energy Conference, Munich, 22-26 October 2001, 368-371.

[19] Diasse, O., Diao, A., Wade, M., Diouf, M.S., Diatta, I., Mane, R., Traore, Y. and Sissoko, G. (2018) Back Surface Recombination Velocity Modeling in White Bias Silicon Solar Cell under Steady State. World Journal of Condensed Matter Physics, 9 , 189-201.

[20] Sissoko, G., Sivoththanam, S., Rodot, M. and Mialhe, P. (1992) Constant Illumination-Induced Open Circuit Voltage Decay (CIOCVD) Method, as Appliedto High Efficiency Si Solar Cells for Bulk and Back Surface Characterization. 11 th European Photovoltaic Solar Energy Conference and Exhibition, Monteux, 12-16 October 1992, 352-354.

[21] Donolato, C. (1999) Effective Diffusion Length of Multicrystalline Solar Cells. Solid State Phenomena, 67-68, 75-80.

[22] Dugas, J. (1994) 3D Modelling of Reverse Cell Made with Improved Multicrisalline Silicon Wafers. Solar Energy Materials and Solar Cells, 32, 71-88.

[23] Oualid, J., Bonfils, M., Crest, J.P., Mathian, G., Amzil, H., Dugas, J., Zehaf, M. and 
Martinuzzi, S. (1982) Photocurrent and Diffusion Lengths at the Vicinity of Grain Boundaries (g.b.) in N and P-Type Polysilicon. Evaluation of the g.b. Recombination Velocity. Revue de Physique Appliquée, 17, 119-124. https://doi.org/10.1051/rphysap:01982001703011900

[24] Ray, U.C. and Agarwal, S.K. (1988) Wavelength Dependence of Short-Circuit Current Decay in Solar Cells. Journal of Applied Physics, 63, 547-549. https://doi.org/10.1063/1.340084

[25] Barro, F.I., Seidou Maiga, A., Wereme, A. and Sissoko, G. (2010) Determination of Recombination Parameters in the Base of a Bifacial Silicon Solar Cell under Constant Multispectral Light. Physical and Chemical News, 56, 76-84.

[26] Dione, M.M., Mbodji, S., Samb, M.L., Dieng, M., Thiame, M., Ndoye, S., Barro, F.I. and Sissoko, G. (2009) Vertical Junction under Constant Multispectral Light: Determination of Recombination Parameters. Proceedings of the 24th European Photovoltaic Solar Energy Conference, Hamburg, 21-25 September 2009, 465-469.

http://www.eupvsec-proceedings.com

[27] Diatta, I., Ly, I., Wade, M., Diouf, M.S., Mbodji, S. and Sissoko, G. (2016) Temperature Effect on Capacitance of a Silicon Solar Cell under Constant White Biased Light World. Journal of Condensed Matter Physics, 6, 261-268. http://www.scirp.org/journal/wjcmp

[28] Ayvazian, G.E., Kirakosyan, G.H. and Minasyan, G.A. (2004) Characteristics of Solar Cells with Vertical p-n Junction. Proceedings of 19 th European Photovoltaic Solar Energy Conference, Paris, 7-11 June 2004, 117-119.

[29] Zoungrana, M., Dieng, B., Lemrabott, O.H., Toure, F., Ould El Moujtaba, M.A., Sow, M.L. and Sissoko, G. (2012) External Electric Field Influence on Charge Carrier and Electrical Parameters of Polycrystalline Silicon Solar Cell. Research Journal of Applied Sciences, Engineering and Technology, 4, 2967-2972.

[30] Ba, F., Seibou, B., Wade, M., Diouf, M.S., Ly, B. and Sissoko, G. (2016) Equivalent Electric Model of the Junction Recombination Velocity Limiting the Open Circuit of a Vertical Parallel Junction Solar Cell under Frequency Modulation. International Journal of Electronics \& Communication, 4, 1-11.

[31] Ngom, M.I., Zouma, B., Zoungrana, M., Thiame, M., Bako, Z.N., Camara, A.G. and Sissoko, G. (2012) Theoretical Study of a Parallel Vertical Multi-Junction Silicon Cell under Multispectral Illumination: Influence of External Magnetic Field on the Electrical Parameters. International Journal of Advanced Technology \& Engineering Research, 2, 101-109.

[32] Mbodji, S., Zoungrana, M., Zerbo, I., Dieng, B. and Sissoko, G. (2015) Modelling Study of Magnetic Field's Effects on Solar Cell's Transient Decay. World Journal of Condensed Matter Physics, 5, 284-293. https://doi.org/10.4236/wjcmp.2015.54029

[33] Diallo, M.M., Tamba, S., Seibou, B., Cheikh, M.L.O., Diatta, I., Ndiaye, E.H., Traore, Y., Sarr, C.T. and Sissoko, G. (2017) Impact of Irradiation on the Surface Recombination Velocity of a Back Side Monochromatic Illuminated Bifacial Silicon Solar Cell under Frequency Modulation. Journal of Scientific and Engineering Research, 4, 29-40.

[34] Hu, C., Carney, J.K. and Frank, R.I. (1977) New Analysis of a High Voltage Vertical Multijunction Solar Cell. Journal of Applied Physics, 48, 442-444. https://doi.org/10.1063/1.323355

[35] Sarfaty, R., Cherkun, A., Pozner, R., Segev, G., Zeierman, E., Flitsanov, Y., Kribus, A. and Rosenwaks, Y. (2011) Vertical Junction Si Micro-Cells for Concentrating Photovoltaics. Proceedings of the 26th European Photovoltaic Solar Energy Confe- 
rence and Exhibition, Hamburg, 5-6 September 2011, 145-147.

[36] Wise, J.F. (1970) Wertical Junction Hardened Solar Cell. US Patent 3, 690-953.

[37] Gover, A. and Stella, P. (1974) Vertical Multijunction Solar-Cell One-Dimensional Analysis. IEEE Transactions on Electron Devices, ED-21, 351-356.

[38] Diallo, H.L., Dieng, B., Ly, I., Dione, M.M., Ndiaye, M., Lemrabott, O.H., Bako, Z.N., Wereme, A. and Sissoko, G. (2012) Determination of the Recombination and Electrical Parameters of a Vertical Multijunction Silicon Solar Cell. Research Journal of Applied Sciences, Engineering and Technology, 4, 2626-2631.

[39] Terheiden, B., Hahn, G., Fath, P. and Bucher, E. (2000) The Lamella Silicon Solar Cell. Proc. 16th European Photovoltaic Solar Energy Conference, Glasgow, 1-5 May 2000, 1377-1380.

[40] Ngom, M.I., Thiam, A., Sahin, G., El Moujtaba, M.A.O., Faye, K., Diouf, M.S. and Sissoko, G. (2015) Influence of Magnetic Field on the Capacitance of a Vertical Junction Parallel Solar Cell in Static Regime, under Multispectral Illumination. International Journal of Pure \& Applied Sciences \& Technology, 31, 65-75.

[41] Kunst, M. and Sanders, A. (1992) Transport of Excess Carriers in Silicon Wafers. Semiconductor Science and Technology, 7, 51-59. https://doi.org/10.1088/0268-1242/7/1/009

[42] Meier, D.L., Hwang, J.-M. and Campbell, R.B. (1988) The Effect of Doping Density and Injection Level on Minority-Carrier Lifetime as Applied to Bifacial Dendritic Web Silicon Solar Cells. IEEE Transactions on Electron Devices, ED-35, 70-79. https://doi.org/10.1109/16.2417

[43] Furlan, J. and Amon, S. (1985) Approximation of the Carrier Generation Rate in Illuminated Silicon. Solid-State Electronics, 28, 1241-1243. https://doi.org/10.1016/0038-1101(85)90048-6

[44] Diao, A., Thiam, N., Zoungrana, M., Sahin, G., Ndiaye, M. and Sissoko, G. (2014) Diffusion Coefficient in Silicon Solar Cell with Applied Magnetic Field and under Frequency: Electric Equivalent Circuits. World Journal of Condensed Matter Physics, 4, 84-92. https://doi.org/10.4236/wjcmp.2014.42013

[45] Diallo, H.L., Wereme, A., Maiga, A.S. and Sissoko, G. (2008) New Approach of Both Junction and Back Surface Recombination Velocities in a 3D Modelling Study of a Polycrystalline Silicon Solar Cell. The European Physical Journal Applied Physics, 42, 203-211. https://doi.org/10.1051/epjap:2008085

[46] Sissoko, G., Museruka, C., Corréa, A., Gaye, I. and Ndiaye, A.L. (1996) Light Spectral Effect on Recombination Parameters of Silicon Solar Cell. World Renewable Energy Congress, Pergamon, Part III, 1487-1490.

[47] Thiam, N., Diao, A., Ndiaye, M., Dieng, A., Thiam, A., Sarr, M., Maiga, A.S. and Sissoko, G. (2012) Electric Equivalent Models of Intrinsic Recombination Velocities of a Bifacial Silicon Solar Cell under Frequency Modulation and Magnetic Field Effect. Research Journal of Applied Sciences, Engineering and Technology, 4, 4646-4655.

[48] Joardar, K., Dondero, R.C. and Schroder, D.K. (1989) A Critical Analysis of the Small-Signal Voltage-Decay Technique for Minority-Carrier Lifetime Measurement in Solar Cells. Solid-State Electronics, 32, 479-483.

[49] Ndiaye, E.H., Sahin, G., Thiam, A., Dieng, M., Diallo, H.L., Ndiaye, M. and Sissoko, G. (2015) Study of the Intrinsic Recombination Velocity at the Junction of Silicon Solar under Frequency Modulation and Irradiation. Journal of Applied Mathematics and Physics, 3, 1522-1535. 
[50] Fossum, J.G. (1977) Physical Operation of Back-Surface-Field Silicon Solar Cells. IEEE Transactions on Electron Devices, 2, 322-325. https://doi.org/10.1109/T-ED.1977.18735

[51] Maxwell, J.C. (1982) Electricity and Magnetism. Calerdon, Oxford, 1.

[52] Yadav, P., Pandey, K., Tripathi, B., Kumar, C.M., Srivastava, S.K., Singh, P.K. and Kumar, M. (2015) An Effective Way to Analyze the Performance Limiting Parameters of a Poly-Crystalline Silicon Solar Cell Fabricated in the Production Line. Solar Energy, 122, 1-10. https://doi.org/10.1016/j.solener.2015.08.005

[53] Selma, M.S.H., Traore, Y., Diatta, I., Diouf, M.S., Wade, M., Habiboulahh, L.O. and Sissoko, G. (2018) Diffusion Capacitance in a Silicon Solar Cell under Frequency Modulated Illumination: Magnetic Field and Temperature Effects. Journal of Scientific and Engineering Research, 5, 317-324.

[54] Mora-Sero, I., Garcia-Belmonte, G., Boix, P.P., Vazquez, M.A. and Bisquert, J. (2009) Impedance Spectroscopy Characterization of Highly Efficient Silicon Solar Cells under Different Illumination Intensities Light. Energy and Environmental Science, 2, 678-686. https://doi.org/10.1039/b812468j

[55] Garland, J.E., Crain, D.J., Zheng, J.P., Sulyma, C.M. and Roy, D. (2011) Electro-Analytical Characterization of Photovoltaic Cells by Combining Voltammetry and Impedance Spectroscopy: Voltage Dependent Parameters of a Silicon Solar Cell under Controlled Llumination and Temperature. Energy \& Environmental Science, 4, 485-498. https://doi.org/10.1039/C0EE00307G 